\title{
Calle Horno del Vidrio-Preliminary Study of Glass Production Remains Found in Granada, Spain, Dated to the 16th and 17th Centuries
}

\author{
Inês Coutinho $^{1, *(\mathbb{D}}$, Isabel Cambil Campaña ${ }^{2}$, Luís Cerqueira Alves ${ }^{3}$ and Teresa Medici $^{4}{ }^{(D)}$ \\ 1 Department of Conservation and Restoration and VICARTE Research Unit, FCT NOVA, \\ 2829-516 Caparica, Portugal \\ 2 Independent Researcher, 18500 Granada, Spain; isabelcambil@gmail.com \\ 3 C2TN, Instituto Superior Técnico, Universidade de Lisboa, 2695-066 Bobadela LRS, Portugal; \\ lcalves@ctn.tecnico.ulisboa.pt \\ 4 VICARTE Research Unit, FCT NOVA, 2829-516 Caparica, Portugal; teresa.medici@gmail.com \\ * Correspondence: icoutinho@fct.unl.pt
}

check for updates

Citation: Coutinho, I.; Cambil Campaña, I.; Cerqueira Alves, L.; Medici, T. Calle Horno del Vidrio_Preliminary Study of Glass Production Remains Found in Granada, Spain, Dated to the 16th and 17th Centuries. Minerals 2021, 11, 688. https://doi.org/10.3390/ $\min 11070688$

Academic Editors: Daniel

Albero Santacreu, José

Cristóbal Carvajal López and Adrián Durán Benito

Received: 14 May 2021

Accepted: 23 June 2021

Published: 26 June 2021

Publisher's Note: MDPI stays neutral with regard to jurisdictional claims in published maps and institutional affiliations.

Copyright: (c) 2021 by the authors. Licensee MDPI, Basel, Switzerland. This article is an open access article distributed under the terms and conditions of the Creative Commons Attribution (CC BY) license (https:/ / creativecommons.org/licenses/by/ $4.0 /)$.

\begin{abstract}
A set of 14 glass fragments and production remains dated to the 16th and 17th centuries was collected during rescue archaeological works conducted in Granada, Spain, and was characterised by $\mu$-PIXE. This preliminary study constitutes the first analytical approach to glass manufacturing remains from a Spanish production dated to the early-modern period. $\mu$-PIXE allowed for the quantification of major, minor and some trace elements of the glass fragments. It also allowed mapping the elemental distribution on the fragments that were identified as an interface of crucible/glass. This analysis constitutes an evaluation of the ionic exchange between glass and crucible. The glass colours vary from the natural green and blue hues to completely colourless samples. The results show that the majority of the glass samples are of soda-lime-silicate composition, and only one proved to be of a potassium-rich composition. From this, one can hypothesise that glass rich in sodium (following the Mediterranean tradition) and potassium-rich glass (following a central and north European tradition) were both locally produced. Since this location was known as la Calle Horno del Vidrio (Glass Furnace Street) and several production evidences were found, it is highly probable that an artisanal glass production existed in this area.
\end{abstract}

Keywords: glass production; Spain; 16th century; $\mu$ PIXE; glass kiln; production remains; objects

\section{Introduction}

Glass manufacturing in Spain during the 16th and 17th centuries was a well-established and flourishing craft. The existence of glass production in the Peninsula is explicitly referred to by written sources from the 12th century onward and the making of luxury glass in Barcelona, Murcia, Malaga and Almería is frequently mentioned by documents. The rapid diffusion of the innovations of the art in the Muslim-ruled area of the Peninsula and the role played by Barcelona in the import and sale of enamelled glass from Syria and Egypt were probably relevant factors for the development of a local production, which ended up being influenced by these imports. The allusions to glass in "Damascus style" appearing in Catalan documents dated to the end of the 14th century and to the first half of the 15th century have been interpreted in this sense [1,2]. Glass production has also been recorded in Valencia and the Baleares, territories that, in the 13th and 14th centuries, formed a political unit with Catalonia, under the Crown of Aragon. A few archaeological objects dated to the 14th century are known, including those found in a kiln excavated at Sant Fost de Campsentelles (Barcelona). They consist mainly of glass of everyday use, with few enamelled fragments [3-5].

At the beginning of the 15th century, the most important technical developments in European glassmaking were achieved in Venice. The accurate selection of raw materials 
and the purification processes allowed for Venetian glassmakers to produce very fine colourless glass, exported to the rest of Europe and to the East. The success of the Venetian production soon led several manufactures in many countries to adopt a Venetian-style production, often employing expatriated Venetian glassmakers, even if they were not legally allowed to work outside the island of Murano. These manufactures attempted to imitate shape and colours, producing the so called façon-de-Venise glass [6].

Façon-de-Venise was a term that first appear in a document in Antwerp dated to 1549, to describe glass objects made outside Venice but following the Venetian tradition in terms of shapes and decorative features [7]. To achieve the quality of the Venetian glass was a desire that rapidly spread through Europe, especially the ability of the Venetian glassmakers to attain a perfectly colourless glass, the cristallo, which became the ultimate object of fascination by the wealthiest collectors [8].

From Venice, luxurious and rare glass objects were also brought to the Iberian Peninsula and the first Venetian glassmakers are documented in Spain already during the first half of the 16th century. The spread of Venetian glassmaking techniques greatly enhanced the 16th and 17th century glass production in the country and the many pieces preserved in the collections of important museums are clear proof of the great value of these creation $[2,9]$.

According to the literature, the two main regions producing façon-de-Venise glass in Spain were Catalunya and Castile [1,2]. The Catalan production during the 16th and the first half of the 17th century was particularly significant. Chalices, footed cups, serving dishes and jugs were blown in thin, high quality colourless or coloured glass. They were often gilded and enamelled or decorated with applied white glass. Among the most common decorative features were the green enamelling and the diamond-point engraving. The colourless glass of Catalan origin appears to have a different hue when compared with other façon-de-Venise European production centres, with shades of smoky yellow or amber [1,2]. Most of these objects had mainly a decorative purpose. They were produced to satisfy the well-known passion for collecting glass that characterised the kings and the nobility $[2,9]$. The data revealed by archaeology, although scarce, provide a more varied picture of the glass circulating in the region, where the more exquisite pieces are accompanied by objects of common use [2]. No kilns connected to the production of the 16th and 17th century are known; the written documents locate two main settings for them, Barcelona and Matarò, a centre in the province of Barcelona [1]. The existence of an important glass activity was recorded in Majorca, which benefitted from the arrival of Venetian masters on the island [5].

In Castile, there is a record of glass furnaces active from the 15th century onward. None of them have been located so far. The Castilian glass preserved in the collections is generally accredited to originate from Cadalso de los Vidrios (Madrid) and Recuenco (Guadalajara). The Venetian style was reinterpreted here in peculiar ways, with singular shapes and using glass with a special hue, especially in the objects identified as coming from the Recuenco's production $[1,2,10]$.

A different character, markedly distinct from the glassware until now examined, is evident in the Andalusian (southern Spain) production. Together with Almería, the main furnaces were in the area of Granada, known for the production of glass since at least the 17th century. Documentary sources refer to furnaces in Castril de la Peña, a municipality located in the province of Granada. Castril production was considered among the most significative in the region [1,11-13]. Castril glasses were exhumed in an archaeological excavation in Murcia, but most information on them stems from written sources and objects preserved in museums collections $[2,11,14]$.

In Almería and Castril, glass of everyday use was produced, such as cups, mugs, jars and bottles. The Andalusian glass is characterised by bright colours: mainly green and yellow (believed to be due to the unintentional presence of iron in the sands), brownishblack, purple and shades of blue. The many bubbles indicate some technological constraint during the fining processes of the melt. Applied decorative elements abound, such as 
threads, ribbons and crested handles [1,2,15]. The glass objects attributed to a Granada provenance are often composed of two coloured glasses combined in one object, for instance, green and amber tonalities. This colourful glass, usually blown with thick walls and considered a direct revivalism of the Islamic repertoire, has been related to Syrian glass dated to the 14th century [1].

It is generally acknowledged that Andalusian glassmakers inherited the Islamic glass manufacturing traditions, including shapes, decorative features and techniques. In Almeria and Granada, the Islamic Al-Andalus influence was present and reflected in the glass production long after the end of the Islamic occupation, that began in the 8th century and lasted until the end of the 15th century. Moreover, the permeability between Christians and Muslims was dynamic and the Islamic influence in the production technology of other materials is undeniable, as is the case with lusterware. As already noted [16], this interconnection and transfer of technology is never restricted to one sole craft.

In the Iberian Peninsula, considering the Portuguese territory, no façon-de-Venise production location has so far been identified. However, a great number of archaeological remains has been unearthed from the north to the south of the territory. Due to the typological and compositional characteristics that some of these objects present, it was proposed that some of the pieces were locally produced [17-19].

Concerning archaeometric studies applied to glass unearthed in Spain, more systematic work is being done to older chronologies, namely to glass assemblages dated to between the 5th and the 12th centuries [20-26], although singular case-studies can also be found for later chronologies [27]. With regard to the southern regions, it was concluded that the glass was of a soda-rich nature; however, glass rich in lead has been systematically identified, which appears to constitute a characteristic of local production, believed to be the result of Islamic influence. During the Nasrid period (roughly dated to between 1230 and 1492), glass production from the Córdoba region appears to be more homogeneous in terms of glass colour and composition, which can be related to a higher control from the authorities and also to the existence of a guild [26]. When traveling south, in Málaga, one faces a different reality, where recycling was very important within the glass production line and in terms of colours the variety is greater. This has been attributed to the position that this city has in the trading routes in the Mediterranean Sea [26]. This shows that even within the Al-Andalus region, one cannot assume an organised and homogeneous production of glass.

The assemblage under study allows for an outstanding opportunity to examine a later chronology, after the Islamic occupation. This research will combine the study of the archaeological context together with historical data, the glass formal characteristics and the determination of its chemical composition in major, minor and some trace elements. Provenance suggestions will be based on the relation of all these aspects. With this study, we hope to contribute to enrich the knowledge about glass production in Europe, specifically the Spanish territory, during the late medieval/early modern periods.

\subsection{Archaeological Context and Description of the Glass Fragments}

A set of 14 glass fragments and production remains was collected during rescue archaeological works conducted in Granada (Spain), at a location known as Calle Horno del Vidrio (Glass Furnace Street). Excavations revealed continuous occupation of the area between the 11th and the 17th-18th centuries, with scant traces of domestic buildings. No evidence of structures related to furnaces was discovered so far. Thus, the massive concentrations of glass wastes led archaeologists to suppose the presence of a glass production site in the immediate surroundings of the excavated parcels (Figure 1). The finds were stratigraphically dated between the 16th and 17th centuries [12].

Considering the 14 fragments under study, three fragments can be identified as probably belonging to objects and nine belong to production remains. Two fragments were collected very close to the crucible walls and will be discussed separately because of the different compositional characteristics (see Table 1). 


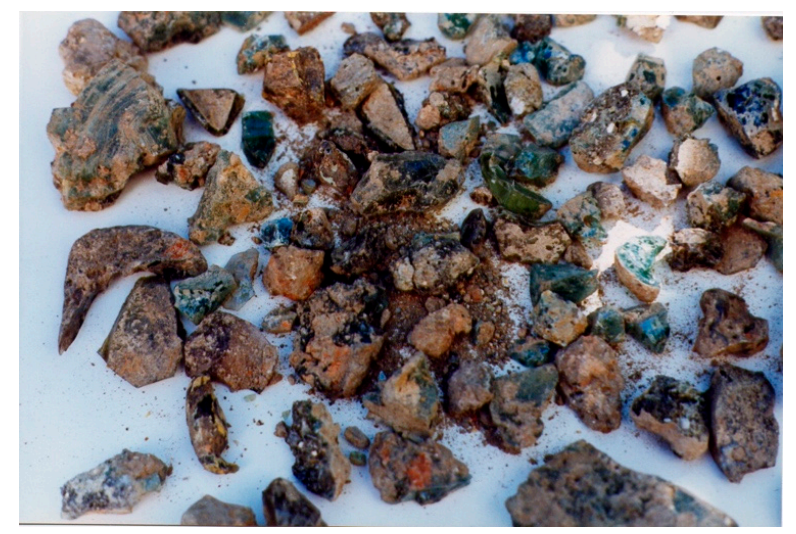

Figure 1. Example of the glass remains found during the excavation at Calle del Horno del Vidrio in Granada, Spain.

Table 1. Description of the fragments under study and the respective photography.

\begin{tabular}{cll}
\hline Inventory Number & \multicolumn{1}{c}{ Fragment Description } \\
\hline & $\begin{array}{l}\text { Fragment of Millefiori decorated glass. It } \\
\text { belongs to the lower part of the object's body, } \\
\text { possibly a small globular vase. } \\
\text { The body is of a transparent blue glass } \\
\text { decorated with an opaque red pick-up } \\
\text { decoration. The degradation layers do not } \\
\text { allow for an appreciation of the colour nor to } \\
\text { interpret the appearance of the applied } \\
\text { murrine. }\end{array}$ \\
\end{tabular}

HV-2

Glass sample collected very close to the crucible wall. It is a fully melted fragment of frit. The colour is a transparent bluish green.
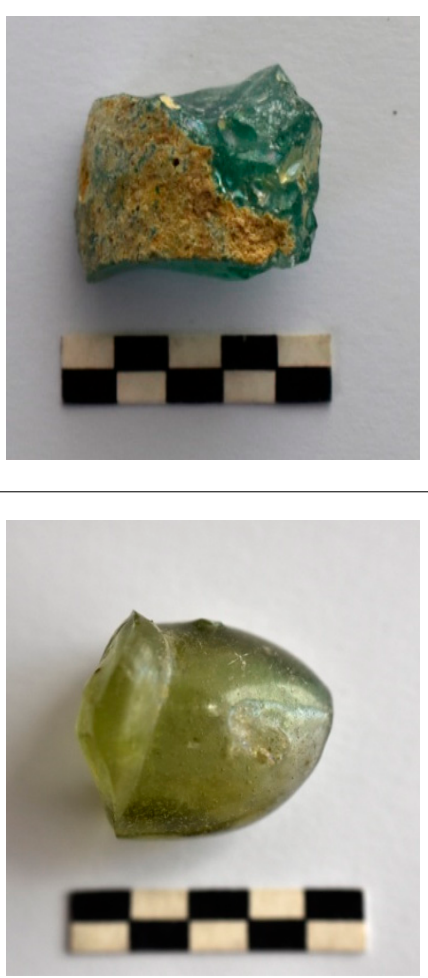
Table 1. Cont.

\begin{tabular}{cll}
\hline Inventory Number & \multicolumn{1}{c}{ Fragment Description } \\
\hline HV-4 & $\begin{array}{l}\text { Object or production waste? Transparent } \\
\text { colorless glass with a slight yellowish green } \\
\text { tone that can be perceived in the thickest } \\
\text { parts. The minimum thickness is half a } \\
\text { millimeter. } \\
\text { It is not clear if this fragment belongs to an } \\
\text { object; the circular opening does not seem to } \\
\text { be part of a piece mouth. }\end{array}$ \\
& \\
\end{tabular}

The fragment could be the mouth of a piece. At the top, it ends as if it were a rounded, straight rim with a thickness less than $3 \mathrm{~mm}$.

HV-5 The maximum thickness at the bottom is 6 $\mathrm{mm}$. The glass is transparent olive green. The fragment is quite irregular and it seems that this was the result of a less cared for production.

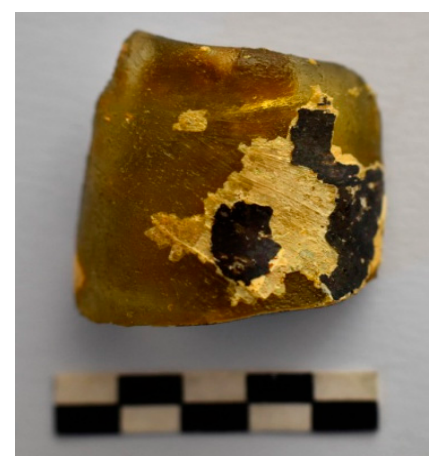

Production waste. Glass can be seen attached on the two faces of a ceramic fragment that could belong to a crucible. The ceramic paste is blackened on the outside. A slightly purple interior of the ceramic paste is visible on the edges of recent cracks. On one side, the glass has an homogeneous layer that has cracked. The other glass layer looks very uneven. The glass is transparent bluish green.

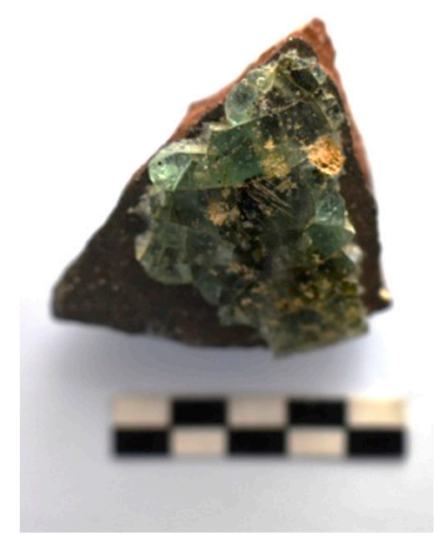

Fragment of a transparent blue glass rod, perfectly cylindrical and it has a $5.5 \mathrm{~mm}$ of diameter at its widest part.

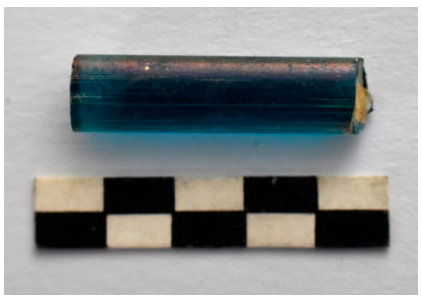


Table 1. Cont.

\begin{tabular}{cll}
\hline Inventory Number & \multicolumn{1}{c}{ Fragment Description } & Photography \\
\hline HV-8 & $\begin{array}{l}\text { Production waste. Opaque green glass. The } \\
\text { narrowest part has a crack that shows a shiny } \\
\text { glass interior. It appears to be a drop. }\end{array}$ \\
\hline
\end{tabular}

Production waste. Deformed glass chunk, fully melted, with a bottle green colour. On one side it has attached impurities that may have come from the furnace wall.

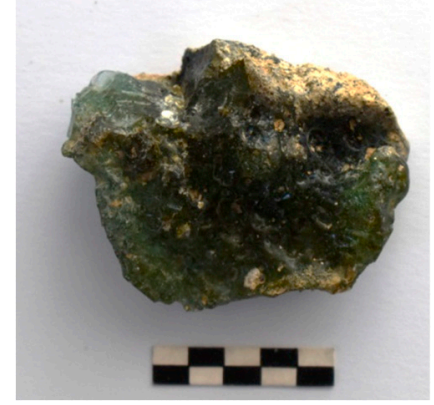

Production waste. Since on one side it has a central area that seems to correspond to a cylindrical shape, it may be of a pontil knock-off.

The glass is transparent green with a slight yellowing hue. Inside one may see a medium-large bubble.

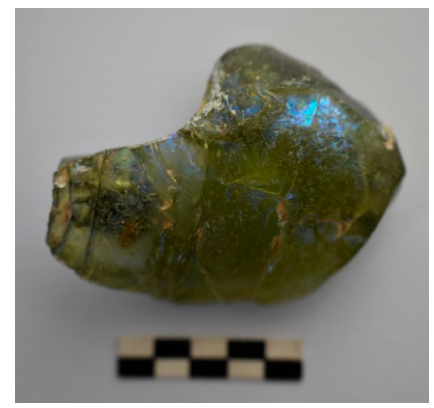

Possible production waste from the interface area where the molten glass gets mixed with the crucible wall. The batch is not fully melted.

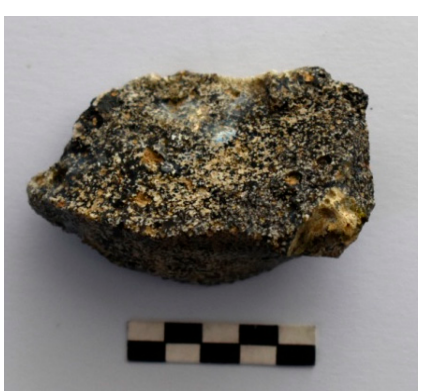

HV-12

Production waste. Glass fragment of transparent bluish colour, fully melted.

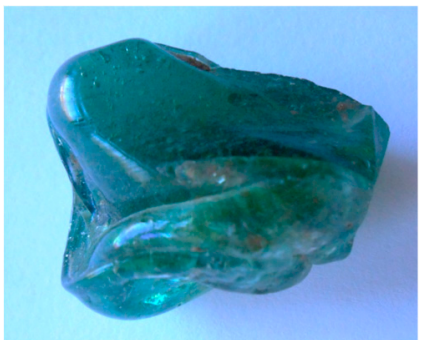


Table 1. Cont.

\begin{tabular}{cll}
\hline Inventory Number & \multicolumn{1}{c}{ Fragment Description } & Photography \\
\hline HV-13 & $\begin{array}{l}\text { Production waste. Glass fragment of bluish } \\
\text { green colour. Although homogeneous, it } \\
\text { seems that the batch did not melt completely } \\
\text { and it seems to present some opacity. }\end{array}$ \\
& \\
HV-14 & $\begin{array}{l}\text { Production waste. It seems that this fragment } \\
\text { might have been attached to the furnace } \\
\text { walls. On one side it has the remains of } \\
\text { material with a totally calcined aspect. The } \\
\text { attached glass is cracked and presents a } \\
\text { transparent bluish green colour. }\end{array}$ \\
\hline
\end{tabular}

The production remains' samples belong to lumps of green/bluish glass, apparently at different degrees of melting; some show the mark left by the blowing cane or by the pontil. The colour of the glass can be compared and related to the glass manufactured during the 16th and 17th century at Castril de la Peña. Castril production is characterised by objects with thick walls in several shades of green and the typologies focus the daily utilitarian needs $[1,13]$. This seems to relate with the type of glass under study here.

The glass of the sampled objects differs. In particular, sample $\mathrm{HV}-4$ is made of colourless glass, with very thin walls and it seems to have belonged to a delicate glass (see Table 1). Sample HV-5, on the other hand, probably belongs to a vessel (shape not identified) with thick walls and a green hue, which is very characteristic of the Castril production type $[1,9,13]$. The third object (sample HV-1) is a fragment of blue glass with red millefiori decoration.

It is more likely that sample HV-4 relates to objects from the Nasrid tradition [12]. Nasrid glass production is characterised by objects with thin walls and less tinted glass (some objects are close to transparent and colourless glass), which seems to indicate two hypotheses: glassmakers from the Nasrid tradition had a greater domain over raw materials and production techniques than the ones that followed and were part of the Castril-type production, or the Castril production was responding to a different taste from the market demand. When looking to the production wastes, apparently, no relation in terms of glass colour can be found between sample HV-4 and the remaining samples.

Finally, the millefiori fragment (sample HV-1) is likely to have been imported. Following what was said for sample HV-4, this fragment has no relation with the production remains recovered by the archaeological excavation. Since façon-de-Venise glass was known to be produced in the Catalonian region, it will be important to try to understand if this fragment was imported from abroad (from Italy for instance) or if it was coming from another Spanish region such as Catalonia.

The relation between the fragments' characteristics (such as glass colour) and compositional results will be explored. The results will be compared with published compositions of coeval glass from Spain and also from other production centres in order to try to propose a provenance for the samples. This will be especially relevant for samples HV-1 and HV-4. 
Regarding the location of the furnaces, it is important to mention that Calle Horno del Vidrio was very close to the Palacio de Castril, a palace whose land was the property of Don Hernando de Zafra, the founder of the glass factory in Castril de la Peña. This location is characterised for having a series of streets with names related to what was being produced there, such as Horno de Vidrio (Glass Furnace) and Horno de Oro (Gold Furnace), among others. This may lead to the hypothesis that these were active crafts in the neighbourhood; however, apart from the glass production remains, no other material remains from these activities had been found so far. Don Hernando de Zafra was secretary of the catholic kings and played a central role during the conquest and organisation of the Granada kingdom [28]. According to M. Garzón Pareja, Don Hernando de Zafra was an entrepreneur, who travelled and got in contact with the Catalonian and the Gerona glass production traditions, which probably was one of the reasons for him to pursue the glass production business, which might have started in smaller furnaces and evolved after to a larger production in the Castril factory [29]. However, other authors believe that glass production at Castril probably started later, after the death of Don Hernando de Zafra [28]. In spite of this discussion, it is safer to assume that if this important figure had any relation with the beginning of glass production at Castril, following the example of other magnates of the time, it would have been as an entrepreneur [28]. It is relevant to clarify that the Castril property and surrounding lands stayed in the de Zafra family long after Don Hernando died [28], which leads to suggest that glass production at Castril may have started during the regency of the de Zafra family.

Noteworthy is the relation this important figure had with the royal family. At the end of the 15th century, glass collecting in Spain started to have some importance among royalty [9]. Later, in the 16th and 17th centuries, it evolved to a different level, where glass also had a prominent place related to its transformative nature. Glass (some produced in Spain) was present in the Spanish royal collections as early as the 15th century [9]; together with the trading and entrepreneurial spirit of Don Hernando de Zafra, this might somehow be related. Looking from different perspectives, it appears that the royal secretary was connected to glass, including trading it and probably establishing and financing its production.

\subsection{Mineralogy of the Silica Source: Implication in the Study of Glass Prodution}

Considering the archaeometric research that has been developed in glass studies, its main focus are the raw materials that compose this material. Raw materials are the group of basic components that are put together and submitted to a transformation process to obtain a final product, in this case glass. The raw materials out of which glass is made can come directly from nature, can be manufactured, or can result from previous recycling actions. In many cases, the combination of the three situations are observed when analysing glass compositions [30]. In the history of glass making, the most frequently used raw materials to obtain silica-the main component and vitrifying agent of glass-are quartz pebbles and sand. The quartz crystal structure is composed of silicon with an ionic valency of $\mathrm{Si}^{4+}$ that, although having a very small ionic size, still has the capacity of incorporating small amount of other elements, such as $\mathrm{Al}, \mathrm{Ti}$ and $\mathrm{Fe}$ [31]. Additionally, apart from the silica, the sand used in the glass batch always contains different types of impurities or accessory minerals, among which one may find clay minerals, iron and titanium oxides, and more complex minerals such as zircon and pyroxenes, among others [31-33]. All these accessory components, including the rare earth elements (REE), will enter the glass batch and become part of the composition of the final pieces. Alumina, iron and titanium oxides are the main elements and trackers for sand, allowing discussion about the provenance of raw materials and, consequently, the provenance of the glass object [34]. 


\section{Materials and Methods}

\subsection{Sample Selection and Preparation}

Samples were selected from the set of production remains (represented in Figure 1), where all fragments presented the same morphological characteristics (such as the glass colour). Some fragments belonging to objects were also selected to be studied. For the choice of these fragments, the criterion was to select among those who presented similar characteristics to the production remains present in Figure 1. In addition, some objects that did not show any resemblance to the production remains from Figure 1 were also selected to be studied, since these may represent objects that might have been made elsewhere.

In order to avoid erroneous results by analysing and quantifying corrosion layers instead of the uncorroded bulk glass, it was decided to sample all selected objects. Small glass samples of $2-4 \mathrm{~mm}^{2}$ were dry cut from the selected glass fragments with a diamond wire. Samples were embedded in an epoxy resin and polished with SiC sandpaper down to 4000 mesh. This sampling procedure was performed only on broken objects and on individual fragments without possible connections.

\section{2. $\mu$-PIXE}

Quantitative results were achieved with the $\mu$-PIXE ion beam analytical technique using an Oxford Microbeams OM150 type scanning nuclear microprobe (the $\mu$-PIXE system is located at the Center for Nuclear Sciences and Technologies- $\mathrm{C}^{2} \mathrm{TN}$, Lisbon University, Lisbon, Portugal) setup with the in-vacuum configuration. To allow efficient detection of low energy X-rays, such as the ones of $\mathrm{Na}$, all the glass fragments were irradiated in vacuum with a focused $0.7 \mathrm{MeV}$ proton beam and the produced X-rays collected by a $8 \mu \mathrm{m}$ thick Be windowed $\mathrm{Si}(\mathrm{Li})$ detector. In order to avoid or detect possible local glass heterogeneities, X-ray imaging (2D elemental distribution) and spectra were generally obtained from an irradiated sample area of $750 \times 750 \mu \mathrm{m}^{2}$. For trace elements quantification (typically elements with atomic number above the one of Fe), a $2 \mathrm{MeV}$ proton beam was used with a $50 \mu \mathrm{m}$ thick Mylar foil positioned in front of the $\mathrm{Si}(\mathrm{Li})$ X-ray detector. Its use as an X-ray filter reduces the strong Si X-ray spectrum contribution, thus allowing an increase of the beam current and accumulated beam charge to attain higher sensitivity (lower detection limits) for elements such as $\mathrm{Cu}, \mathrm{As}$ and $\mathrm{Sb}$. The samples were also coated with a thin carbon layer in order to prevent sample beam-charging, and consequently, $X$-ray spectra degradation. Operation and basic data manipulation, including elemental distribution mapping, was achieved through the OMDAQ software code (version 5.1, Oxford Microbeams, Oxford, UK), and quantitative analysis with the GUPIX program (version 2.1.4, University of Guelph, Guelph, Ontário, Canada) [35]. The results are expressed in weight percentage of oxides and were normalised to $100 \%$. To validate the obtained concentration results, a glass reference standard, Corning B, was also analysed. Those values are presented in Table 2. The measurements uncertainties were considered as the combined uncertainties of spectra counting statistics and spectra deconvolution fit uncertainty. This implies a relative uncertainty below $1 \%$ for $\mathrm{SiO}_{2}$, below $5 \%$ for $\mathrm{Na}$ (except for $\mathrm{HV} 8$ sample), $\mathrm{Mg}$, $\mathrm{Al}, \mathrm{K}$ and $\mathrm{Ca}$ oxides and below $30 \%$ for all the remaining oxides. 
Table 2. Chemical composition of the samples from Horno del Vidrio, Granada, determined by $\mu$-PIXE, in weight percent of oxides.

\begin{tabular}{|c|c|c|c|c|c|c|c|c|c|c|c|c|c|c|c|c|c|c|c|c|c|}
\hline Sample & $\mathrm{Na}_{2} \mathrm{O}$ & $\mathrm{MgO}$ & $\mathrm{Al}_{2} \mathrm{O}_{3}$ & $\mathrm{SiO}_{2}$ & $\mathrm{P}_{2} \mathrm{O}_{5}$ & $\mathrm{SO}_{3}$ & $\mathrm{Cl}$ & $\mathrm{K}_{2} \mathrm{O}$ & $\mathrm{CaO}$ & $\mathrm{TiO}_{2}$ & $\mathrm{MnO}$ & $\mathrm{Fe}_{2} \mathrm{O}_{3}$ & $\mathrm{CoO}$ & $\mathrm{NiO}$ & $\mathrm{CuO}$ & $\mathrm{ZnO}$ & $\mathrm{As}_{2} \mathrm{O}_{5}$ & $\mathrm{Rb}_{2} \mathrm{O}$ & SrO & $\mathrm{BaO}$ & $\mathrm{PbO}$ \\
\hline \multicolumn{22}{|l|}{$\begin{array}{l}\text { Production remains and Glass } \\
\text { fragments }\end{array}$} \\
\hline HV-1 & 14.2 & 4.0 & 2.1 & 59.4 & 0.24 & 0.16 & 0.61 & 6.09 & 10.04 & 0.14 & 1.28 & 0.93 & 0.08 & 0.076 & 0.06 & 0.01 & 0.23 & 0.01 & 0.11 & 0.10 & 0.03 \\
\hline HV-3 & 16.6 & 2.3 & 3.7 & 63.2 & 0.24 & 0.14 & 0.66 & 5.82 & 5.12 & 0.27 & 0.60 & 1.06 & $<0.01$ & 0.01 & 0.01 & 0.01 & $<0.01$ & 0.01 & 0.08 & 0.10 & 0.09 \\
\hline HV-5 & 15.2 & 3.9 & 2.9 & 57.9 & 0.24 & 0.25 & 0.51 & 6.50 & 10.41 & 0.19 & 0.68 & 1.07 & $<0.02$ & 0.01 & 0.05 & 0.01 & 0.01 & 0.01 & 0.10 & 0.07 & $<0.01$ \\
\hline HV-6 & 16.8 & 2.2 & 3.8 & 63.7 & 0.27 & 0.11 & 0.79 & 5.71 & 5.02 & 0.29 & 0.09 & 0.95 & $<0.01$ & 0.01 & 0.01 & 0.01 & $<0.01$ & 0.01 & 0.07 & $<0.06$ & 0.02 \\
\hline HV-7 & 19.7 & 1.8 & 3.8 & 60.5 & 0.23 & 0.18 & 0.85 & 3.84 & 5.84 & 0.22 & 0.02 & 1.09 & 0.040 & 0.03 & 1.57 & 0.04 & 0.16 & 0.01 & 0.04 & 0.04 & 0.04 \\
\hline HV-8 & 1.2 & 1.4 & 4.2 & 71.0 & 0.27 & $<0.01$ & 0.02 & 13.91 & 5.64 & 0.31 & 0.06 & 1.72 & $<0.02$ & $<0.01$ & 0.01 & 0.01 & $<0.01$ & 0.01 & 0.05 & 0.07 & $<0.01$ \\
\hline HV-9 & 15.5 & 2.1 & 3.7 & 64.7 & 0.23 & 0.16 & 0.64 & 6.62 & 4.94 & 0.30 & 0.04 & 0.96 & $<0.01$ & 0.01 & 0.00 & 0.01 & $<0.01$ & 0.01 & 0.07 & $<0.07$ & $<0.01$ \\
\hline HV-10 & 17.0 & 2.5 & 3.5 & 61.1 & 0.23 & 0.19 & 0.65 & 6.88 & 5.39 & 0.29 & 0.84 & 1.03 & $<0.02$ & 0.01 & 0.03 & 0.01 & $<0.01$ & 0.01 & 0.08 & 0.11 & 0.09 \\
\hline HV-13 & 16.7 & 2.2 & 3.6 & 63.9 & 0.21 & 0.13 & 0.83 & 5.91 & 5.07 & 0.34 & 0.08 & 0.94 & $<0.02$ & 0.01 & 0.00 & 0.01 & $<0.01$ & 0.01 & 0.06 & 0.03 & $<0.01$ \\
\hline HV-14 & 15.6 & 2.2 & 3.6 & 64.5 & 0.19 & 0.13 & 0.82 & 5.95 & 5.38 & 0.31 & 0.04 & 1.11 & $<0.02$ & 0.01 & 0.00 & 0.01 & $<0.01$ & 0.01 & 0.07 & 0.04 & $<0.01$ \\
\hline \multicolumn{22}{|l|}{ Glass Waste and Crucibles } \\
\hline $\mathrm{HV}-2$ & 6.2 & 1.5 & 11.0 & 65.0 & 1.27 & 0.45 & 2.86 & 2.89 & 5.61 & 0.81 & 0.05 & 2.11 & $<0.02$ & $<0.01$ & 0.01 & 0.01 & $<0.01$ & $<0.01$ & 0.07 & 0.08 & $<0.01$ \\
\hline $\begin{array}{l}\text { HV-11 (Crucible/Glass } \\
\text { interface, area richer in } \mathrm{Al} \text { ) }\end{array}$ & 0.9 & 1.7 & 13.4 & 62.6 & 0.53 & $<0.02$ & $<0.01$ & 5.82 & 7.50 & 0.87 & 0.09 & 6.16 & $<0.05$ & 0.01 & 0.01 & 0.02 & $<0.01$ & $<0.02$ & 0.08 & $<0.02$ & $<0.02$ \\
\hline $\begin{array}{l}\text { HV-11 (Crucible/Glass } \\
\text { interface, area richer in Si) }\end{array}$ & 0.2 & 0.2 & 6.2 & 88.9 & $<0.04$ & $<0.02$ & $<0.01$ & 1.90 & 0.22 & 0.32 & $<0.02$ & 1.84 & $<0.02$ & $<0.001$ & $<0.004$ & $<0.002$ & $<0.004$ & $<0.01$ & $<0.01$ & $<0.06$ & $<0.01$ \\
\hline \multicolumn{22}{|l|}{ Glass Standard } \\
\hline CMoG B-Measured & 16.1 & 1.0 & 4.1 & 61.2 & 0.62 & & & 1.25 & 8.28 & 0.10 & 0.2 & 0.3 & 0.050 & & 2.63 & 0.17 & & & 0.02 & 0.08 & 0.48 \\
\hline
\end{tabular}




\section{Results and Discussion}

The studied material can be divided in: glass waste and glass remains attached to crucibles or furnace walls, production remains of loose glass and, finally, glass fragments from objects. The presentation and discussion of the results will be made following this division and a relation between production remains and the objects' fragments will be made.

From the 14 samples that were analysed, it was possible to determine the type of glass for 12 of the samples. For these 12 samples, 11 are of a soda-rich silica glass and only 1 (sample HV-8) was identified as being of a potassium-rich glass. Two samples, still attached to the crucible material, do not present alkali values that permit a glass type identification.

For the soda-lime-silica glass, the contents of $\mathrm{MgO}(1.5-4.2 \mathrm{wt} \%), \mathrm{K}_{2} \mathrm{O}(3.8-6.9 \mathrm{wt} \%)$, $\mathrm{P}_{2} \mathrm{O}_{5}(0.2-0.4 \mathrm{wt} \%)$ and the presence of chlorine $(>0.5 \mathrm{wt} \%)$ are consistent with the use of coastal plant ashes, the usual alkali source identified for Mediterranean glass productions, such as the Venetian one $[37,38]$.

Results and discussion are divided in a Glass Waste and Crucibles section and Production Remains and Glass Fragments section to help explore results and identify relations, similarities and differences among data. The obtained glass composition will be compared with coeval glass from Spain and from other production centres.

\subsection{Glass Waste and Crucibles}

Samples HV-2 and HV-11 are the ones considered to belong to this category. Sample HV-2 was collected very close to the crucible wall and presents alkali values that prevent us to discuss its nature (see Table 2). This was confirmed by the very high level of alumina $(11.0 \mathrm{wt} \%)$, and for this reason, no further conclusions were explored for sample HV-2.

Considering sample HV-11, due to the aspect of the fragment, it seemed to come from the interface area where the molten glass gets mixed with the crucible wall. It has a blackish/greyish colour and there was a great number of bubbles or pores present in the sample. A $\mu$-PIXE mapping was performed on the fragment in order to observe the distribution of some elements in the sample (Figure 2). It is possible to observe an area richer in $\mathrm{Si}$, which is also richer in $\mathrm{Ca}$ and $\mathrm{K}$. This area is probably the one closer to the crucible, which is the area more susceptible to ionic exchange [39].

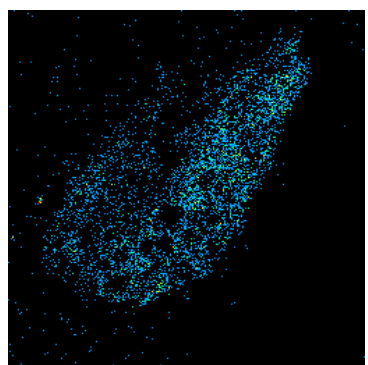

$\mathrm{Si}$

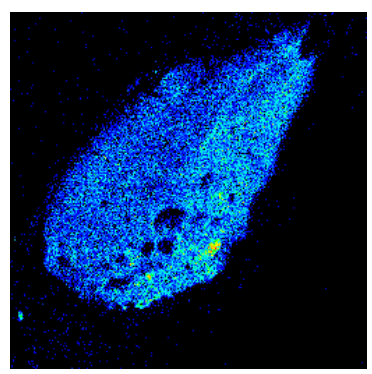

$\mathrm{Ca}$

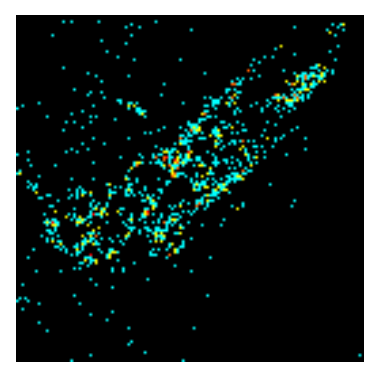

Al

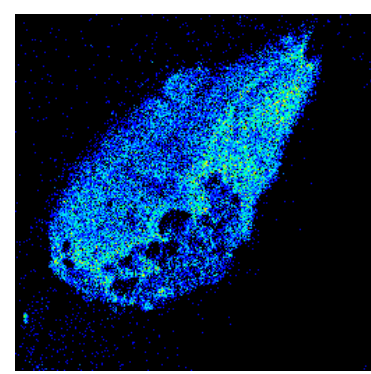

K
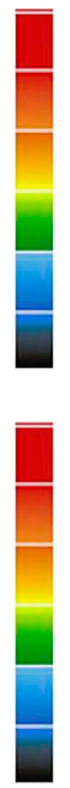

Figure 2. Cont. 

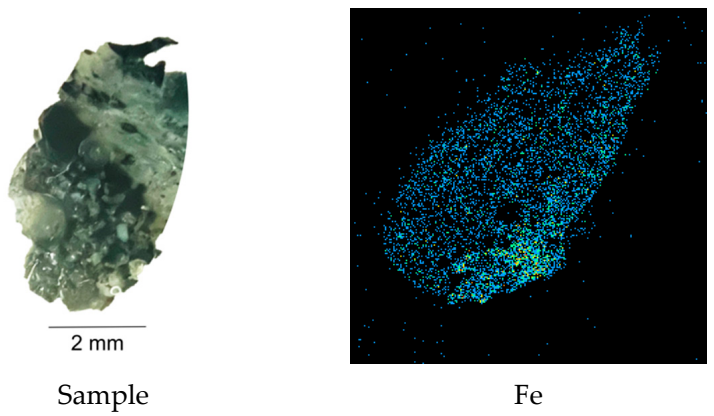

$\mathrm{Fe}$

Figure 2. $\mu$-PIXE elemental distribution in sample HV-11 for elements $\mathrm{Si}, \mathrm{Al}, \mathrm{Ca}, \mathrm{K}$ and $\mathrm{Fe}$. The two maps on top row have dimensions of $2.25 \times 2.25 \mathrm{~mm}^{2}$ and were obtained with a $0.7 \mathrm{MeV}$ proton beam and the remaining maps have dimensions of $2.64 \times 2.64 \mathrm{~mm}^{2}$ and were obtained with a $2 \mathrm{MeV}$ proton beam.

\subsection{Production Remains and Glass Fragments}

\subsubsection{Silica Sources}

Before looking at the samples of production remains and glass fragments separately, in Figure 3, the main components of the silica source for all these samples are plotted in order to verify if the assumptions made previously when looking to the glass colours and forms, could be verified.

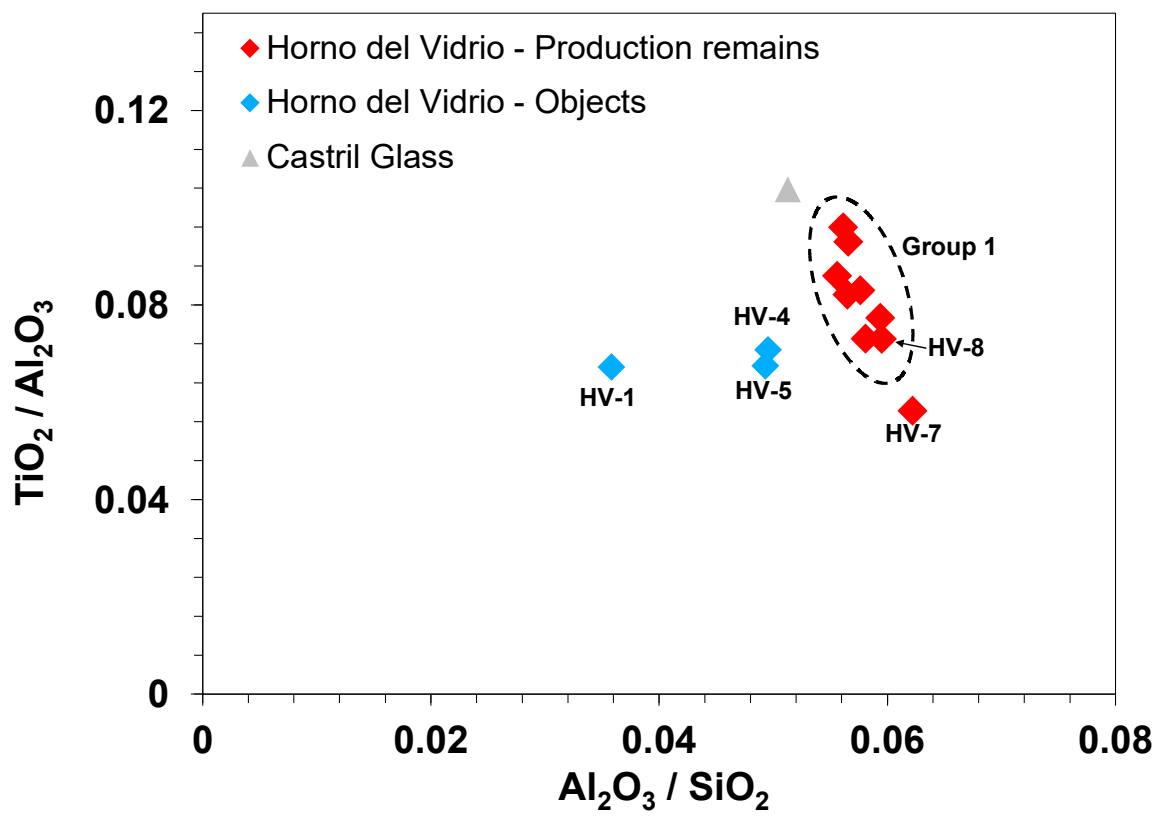

Figure 3. Binary plot of weight ratios of $\mathrm{Al}_{2} \mathrm{O}_{3} / \mathrm{SiO}_{2}$ vs. the weight ratio of $\mathrm{TiO}_{2} / \mathrm{Al}_{2} \mathrm{O}_{3}$. The Castril Glass values were taken from [13].

The plot shown in Figure 3 allows for the comparison of the mineralogy of the glassmaking sands. As mentioned previously, titania and alumina are among the most important oxides to study the origins of the silica source. With the presented combination of oxides, it is possible to create a chart where the mineralogical characteristics of the silica raw material is related to the glass composition, namely the quartz content $\left(\mathrm{SiO}_{2}\right)$, the feldspar contribution $\left(\mathrm{Al}_{2} \mathrm{O}_{3}\right)$ and the heavy minerals contribution $\left(\mathrm{TiO}_{2}\right)$ [40,41]. This relation suggests that the group of eight samples marked with an oval dashed line (designated Group 1) and which represents the majority of production remain samples with very similar green/bluish hues are also very similar in terms of the composition of the silica source, strongly suggesting that these glass samples were made from the same source of silica. 
What is very interesting and noteworthy is that this group, composed of soda-lima-silica glass, includes a glass drop with the only potassium-rich composition (sample HV-8) found in the set, which seems to indicate that despite the fact that a different flux and consequently a different recipe were used, the silica source is the same used for the production of the batch with a sodium-rich composition. All samples within this group were identified as belonging to production remains (samples HV-3, HV-6-10 and HV-12-14) while presenting a greenish/bluish colour, which seems to be in accordance with the Castril production style [12].

Still looking to the binary plot represented in Figure 3, the composition of the glass samples retrieved from Granada were also compared with the published composition for Castril glass [13]. One can find a very straight relation between the Castril glass composition and the analysed samples shown within the oval dashed line of Figure 3. Together with the previously mentioned Castril characteristics, this group of eight samples can be clearly correlated to the Castril glass.

The second relation that can be identified is between samples HV-4 and HV-5. As one can see in Table 1, sample HV-4 was collected from a colourless and thin fragment (shape not identified), possible related to a Nasrid tradition. Sample HV-5, on the other hand, probably belongs to a vessel (shape not identified) with thick walls and a light green hue, very characteristic of the Castril production type. Due to the similarity of the two samples in terms of the mineralogic characteristics of the glass, it is proposed that for both samples, the same source of silica was employed. This seems to suggest that the same silica source was being exploited during different chronological periods, such as the Nasrid and the Castril ones. This hypothesis needs to be further explored, since it is not possible to fully understand such a relation with only two samples showing this behaviour. It is also important to notice that these two samples are somehow close to the group of samples previously described, which may indicate that, even though these two glasses were made with a different source of silica, these were not probably very distant (geographically) from each other.

Looking now to the two samples that appear isolated on the chart from Figure 3, sample HV-7, which belongs to a blue rod, is similar to the main group of samples firstly described here. Following what was proposed previously for the group of two samples (HV-4 and HV-5), it seems that the silica source used for the making of sample HV-7 is geographically related to the one used for Group 1 samples. Regarding sample HV-1, this sample stands out on account of its decorative feature: a blue glass body with millefiori decoration in red glass. Concerning its composition, it also appears completely separated from all the other samples, showing no relation with the other glass, having the poorest content in alumina and titania from all characterised samples. However, despite these low values, the body glass has alumina and titania contents higher than the ones that have been measured for genuine Venetian glass so far, preventing in this way to attribute this fragment to a genuine Venetian production [42,43]. Two hypotheses can be considered: either the fragment is of local production or it was imported from elsewhere. When comparing the composition of this fragment with the other analysed remains, it is clear that it cannot be compared with any, which seems to indicate that the second hypothesis is more likely to be correct. It is, however, very interesting that a millefiori fragment was found amongst the glass production remains. This fragment might have been part of a piece from a habitational house and just got mixed with the furnace production remains or collected for recycling. Other façon-de-Venise glass were found during the excavations and these were considered imported products, either from Venice or from other Spanish locations such as Catalonia, known for its façon-de-Venise production of high quality, or as Castille, where during the 16th and 17th centuries, the production of façon-de-Venise glass was of outstanding quality and manufactured by immigrant glassmakers from Venetian and Flemish origins [12,44]. 


\subsubsection{Alkali Sources}

When studying the alkaline sources, the great majority of the analyzed glass is of a soda-rich composition, with the exception of one fragment which is of a potassium-rich composition (sample HV-8). Looking to Figure 4, the fractions of $\mathrm{Na}_{2} \mathrm{O}$ and $\mathrm{K}_{2} \mathrm{O}$ were normalised to the content of all alkaline and alkaline-earth oxides and plotted, in order to observe the distinct fractions of these oxides employed in the flux, and consequently, to distinguish amongst the different possible fluxes employed in the glass.

The two dashed lines marked on the chart (Figure 4) represent the use of unpurified ashes (correlation line of $\mathrm{Na}_{2} \mathrm{O}^{*}+\mathrm{K}_{2} \mathrm{O}^{*}=0.6$ ) and purified ashes $\left(\mathrm{Na}_{2} \mathrm{O}^{*}+\mathrm{K}_{2} \mathrm{O}^{*}=0.75\right.$ ). $\mathrm{Na}_{2} \mathrm{O}^{*}$ and $\mathrm{K}_{2} \mathrm{O}^{*}$ values are obtained through the division of the respective oxide by every com-ponent introduced by the ash $\left(\mathrm{Na}_{2} \mathrm{O}, \mathrm{MgO}, \mathrm{P}_{2} \mathrm{O}_{5}, \mathrm{~K}_{2} \mathrm{O}\right.$ and $\left.\mathrm{CaO}\right)$. The purification of vegetable ashes was introduced in glassmaking during the 15th century in Murano. The ashes were ground, dissolved in water and then boiled. The resulting solution was filtered and left to dry. These steps led to the formation of a white salt—sale da cristallo- that was mixed with the silica source in the right proportion, and calcined in order to obtain Cristallo glass [37]. This purification process resulted in the removal of iron compounds as well as calcium and magnesium, the presence of these last two being essential to the chemical stability of the glass. Unpurified ashes refer to the use of the same vegetable ahes with no treament applied. In this period, the source of alkali used by the Venetians was inported from Levantine region; however, in the Spanish mediterranean coast line, barrilla (Salsola soda) was mostly likely the source for the ashes, with the Alicante barrilla being the most famous one for glass production $[37,45]$.

Adding to the samples from the Granada glass furnace, the values for Castril glass for the 14th/15th century Portuguese glass from Beja (PMF) and the values for 1the 5 th/16th century glass from Savona, Italy (two samples) were also plotted. The areas for Levantine treated ash (usually related to Cristallo), Levantine untreated ash (usually related to Vitrum Blanchum and Venetian common glass), 16th/17th century façon-de-Venise glass from different provenances, 17th century mixed alkali glass and 17th century potassiumrich glass, the latter two both made by employing purified raw materials, were marked on the chart to help visualising where the Granada glass samples would correlate the most.

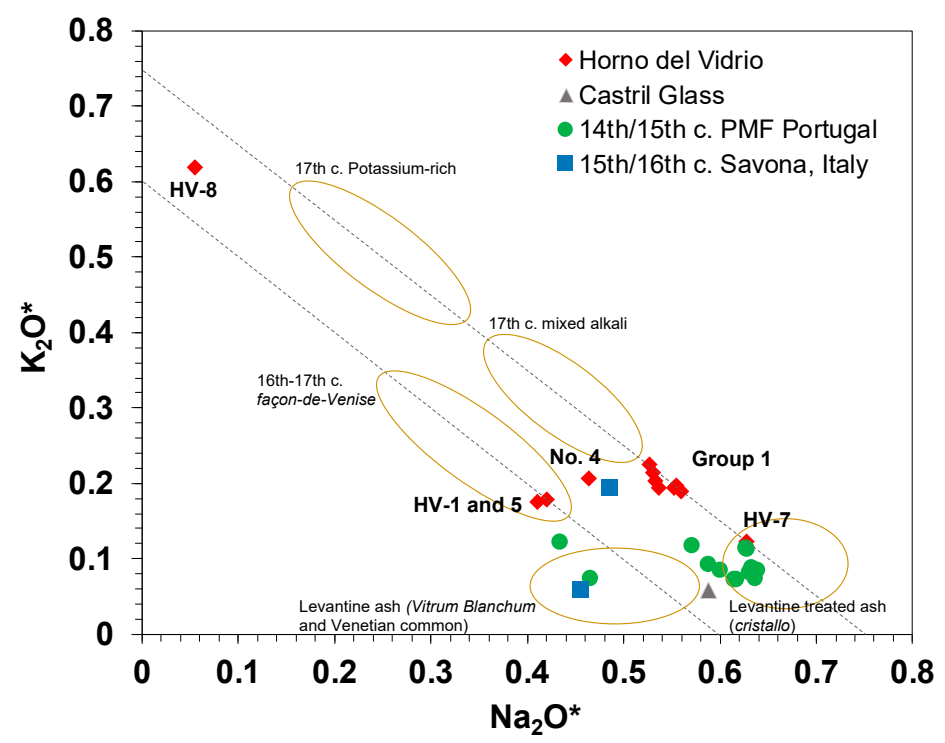

Figure 4. Binary plot of $\mathrm{Na}_{2} \mathrm{O}^{*}$ vs. $\mathrm{K}_{2} \mathrm{O}^{*}$. $\mathrm{Na}_{2} \mathrm{O}^{*}$ and $\mathrm{K}_{2} \mathrm{O}^{*}$ values are obtained through the division of the respective oxide by every component introduced by the ash $\left(\mathrm{Na}_{2} \mathrm{O}, \mathrm{MgO}, \mathrm{P}_{2} \mathrm{O}_{5}, \mathrm{~K}_{2} \mathrm{O}\right.$ and $\mathrm{CaO})$. The two correlation lines represent the purified ash $\left(\mathrm{Na}_{2} \mathrm{O}^{*}+\mathrm{K}_{2} \mathrm{O}^{*}=0.75\right)$ and the unpurified ash $\left(\mathrm{Na}_{2} \mathrm{O}^{*}+\mathrm{K}_{2} \mathrm{O}^{*}=0.6\right)$ [46]. Samples from the Horno del Vidrio were plotted together with Castril glass [13], 14th/15th century PMF samples [17] and 15th/16th century glass from Savona, Italy [46]. 
Analysing the chart from Figure 4, it can be immediately observed that samples identified in Group 1 appear again all together aligned on the correlation line that belongs to the employment of purified ashes; however, in a different way than the Levantine ashes employed in the Venetian Cristallo glass. The purified Levantine ashes have a lower $\mathrm{K}_{2} \mathrm{O}^{*}$ value, which implies higher soda contents. The ashes employed for the production of Group 1 samples have a higher $\mathrm{K}_{2} \mathrm{O}^{*}$ value, and as far as we know, no other coeval samples showing this behaviour have been reported in the literature. One can hypothesise that local plants rich in sodium were being purified and employed in the production of this group of samples with similar characteristics to Castril glass. What is interesting to notice is that Castril glass appears much lower on the chart, very close to PMF samples, showing no relation with Group 1 Granada samples.

When looking to the other plotted samples from the Granada furnace, samples HV-1 and HV-5 appeared in close proximity to each other in the area identified for the 16th/17th century façon-de-Venise glass from different provenances. This is in accordance with what had already been verified when the silica sources were discussed. Sample HV-1, which belongs to millefiori glass, showed characteristics for the silica source not compatible with genuine Venetian glass. This is emphasised when studying the alkaline source, since no relation with the use of Levantine ashes (purified or non-purified) is identified and, on the other hand, the glass seems to be in accordance with the recipes used for façon-de-Venise glass produced throughout all Europe. Concerning sample HV-5, no shape or decoration feature is perceived that allows for a deeper discussion; however, one can suggest that a very similar source and recipe for alkaline content was used for both samples HV-1 and HV-5.

Regarding sample HV-7, it falls within the boundaries for Levantine treated ash. This fragment, which seems to belong to a glass rod, was made employing Levantine treated ashes. When crossing this information with the study of the silica source, it seems that this fragment was probably locally made (the silica source seems highly related to the Group 1 Si source).

When looking at sample HV-4, it appears related to one sample from Savona, Italy. The Savona sample was identified as been made with a type of ash that was named as West Mediterranean Ash (WMA). This alkaline source is characterised by being produced with a soda-rich ash with a higher potassic content when compared with the Levantine one [46]. According to Cagno et al. (2012), there are different possibilities for the origin of this flux, with the most probable being a mixture of plant ashes from different origins.

Finally, sample HV-8 shows a very different behaviour than expected, since this sample has a potassium-rich composition. This sample appears in the upper part of the chart and does not relate with 17th century potassium-rich glass made using purified ashes. It is important to recall that this sample, in terms of silica source, falls within Group 1, which was identified as to probably have been made with a local source related to Castril glass.

In sum, raw materials from different sources were identified in the Calle Horno del Vidrio samples, especially with regards to alkaline sources. Not only different sources, but also different recipes were identified, showing that the knowledge circulation and also probably glassmakers' circulation was very active in this period. Additionally, the adaptation of recipes to local raw materials seems to be a normal procedure. However, more samples need to be analysed to further explore these results.

\subsection{Iberian Peninsula and beyond}

In Figure 5, a comparison between the production remains and the pieces from Granada furnace was made with coeval glass from other Spanish, Italian and Portuguese contexts to try to identify differences and similarities $[13,18]$. 


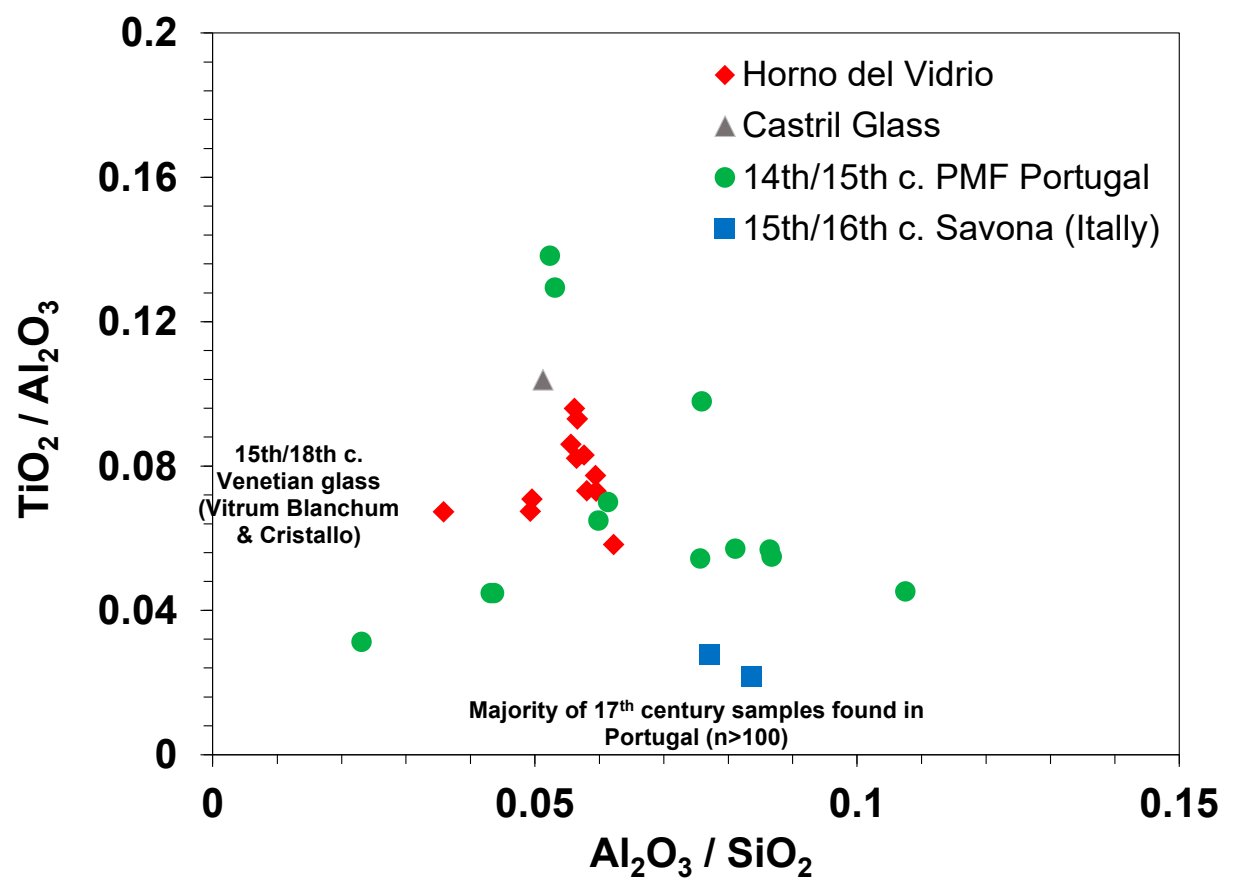

Figure 5. Binary plot of weight ratios of $\mathrm{Al}_{2} \mathrm{O}_{3} / \mathrm{SiO}_{2}$ vs. the weight ratio of $\mathrm{TiO}_{2} / \mathrm{Al}_{2} \mathrm{O}_{3}$ for the samples from the Horno del Vidrio together with the Castril glass, the 14th/15th century glass unearthed in Beja, Portugal (PMF) and the 15th/16th century glass from Savona, Italy [13,46,47].

Again, here, concerning Spanish contexts for this chronology, only the analytical results for Castril glass samples were used, since no other published compositions for glass from this chronology were found. As discussed before, one may find a straight relation between the cohesive group of eight samples and the Castril glass, indicating that probably, the same source of silica was used to produce the group of samples from Granada.

Concerning the comparison with glass found in Portugal, it was decided to compare with samples dated to the 14th up to the 17th century [18]. In Figure 5, one can see the ratios of alumina/silica versus titania/alumina for the Granada samples, the Castril glass [13] and for the 14/15th centuries Praça Miguel Fernandes (Beja) samples (PMF) [47]. Still, in Figure 5, a grey shadow was marked, which represents the area to which the great majority of the Portuguese samples dated to the 17th century belong (more than 100 samples) [18]. It is possible to propose that 17th century glass samples unearthed in Portugal and some samples from the 14/15th centuries from PMF assemblage were made with different silica sources that do not compare with the Granada samples or with Castril glass. The silica source employed in the glass found in Spain have different mineralogical characteristics when compared with the ones employed for 17th century glass found in Portugal.

What is striking when analysing the binary chart in Figure 5 is the resemblance of two samples dated to the 14th/15th century from PMF assemblage, with glass from Granada, more specifically from Group 1 samples. The two PMF samples are made of colourless glass, with very thin walls, resembling Nasrid glass. These fragments belong to two drinking glasses. Fragment PMF0401 is a colourless glass with a natural light yellow hue, and it belongs to a drinking glass with a cylindrical or cylindrical-conical body, with vertical ribs that resulted from mould-blowing, and has a string applied from the same glass that composes the body [19]. Some objects decorated with mould-blown ribs and applied glass strings were found among the Nasrid glass from the Alhambra Museum collection; however, these are not from drinking glasses but belong to jars instead [44]. Fragment PMF0691 is colourless with a natural light greenish hue, and it belongs to a drinking glass with a foot, blown into a mould, which gave the object vertical ribs. No parallel for this type of shape was found among Nasrid glass so far. Since these two PMF fragments are comparable with Group 1 samples (with Castril glass characteristics) and the same source 
of silica was probably employed for the production of both PMF and Granada samples, this might indicate that this specific silica source was used for the production of glass with different characteristics and probably during a long period of time.

Finally, concerning sample HV-1, which belongs to a blue glass with millefiori decoration, in Figure 6, the contents of alumina and iron oxide for this sample were plotted and compared with façon-de-Venise glass from different production locations. It is possible to see that this millefiori sample is quite distant from the region defined for the genuine Venetian Cristallo and Vitrum Blanchum glass. This comes in accordance with what was said before about this sample not being of genuine Venetian provenance. Granada sample appears close to one of the millefiori samples that was found in the excavations performed to the Monastery of Santa Clara-a-Velha in Coimbra, Portugal [48]. Most studied millefiori fragments from the Monastery of Santa Clara-a-Velha in Coimbra were not compatible with genuine Venetian glass or even with known façon-de-Venise production centres. The millefiori fragment from Granada furnace seems to follow the same tendency, and even though it seems to be related to one of the Santa Clara-a-Velha monastery, Coimbra (SCV) millefiori samples, no probable provenance can currently be proposed for this fragment.

What is striking and worth mentioning is that, in the majority of the literature available about millefiori glass, this decorative technique is mainly attributed to a genuine Venetian provenance because of the complexity that its production involves. It is, however, clear that by looking into Figure 6, millefiori glasses found in Portugal, Amsterdam, Antwerp, London and Tuscany cannot be attributed to a Venetian production, which seems to suggest that the production of these glasses was more spread that one might expect, a hypothesis that has already been proposed elsewhere [49].

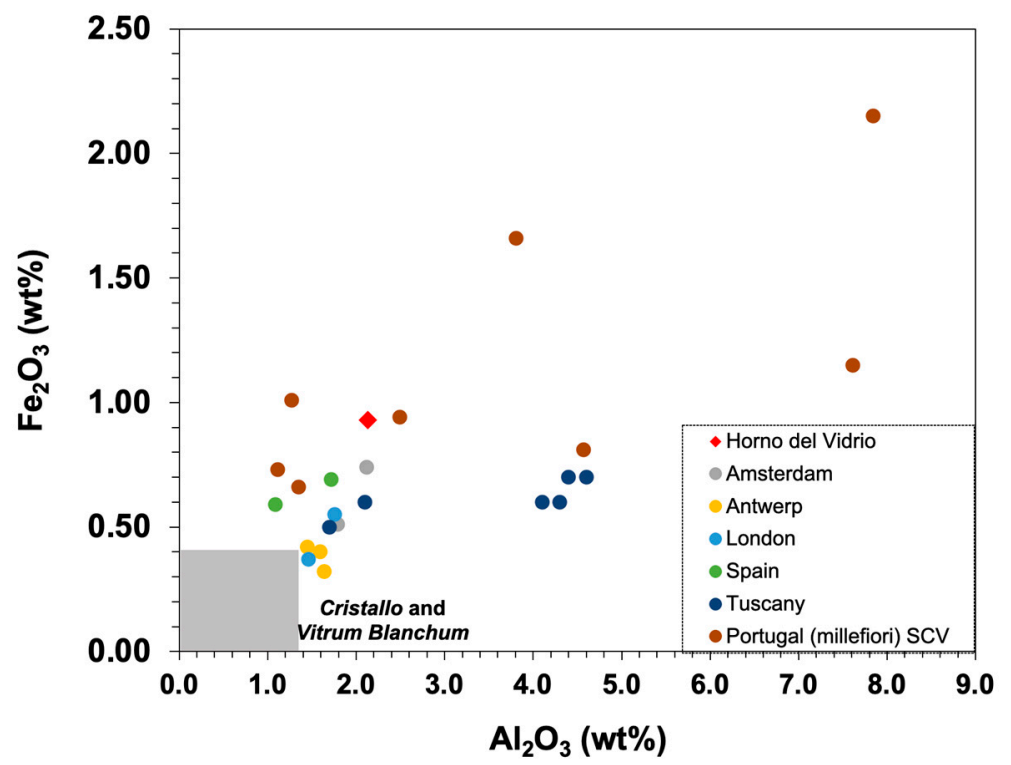

Figure 6. Binary chart of alumina versus iron oxide in weight percent of oxides. The grey shadow represents the values for genuine Venetian cristallo and vitrum blanchum. Samples from Amsterdam, Antwerp, London, Spain and Tuscany belong to façon-de-Venise glass that was locally produced and, finally, the Portuguese samples belong exclusively to millefiori fragments unearthed in the Santa Clara-a-Velha Monastery in Coimbra.

\section{Conclusions}

A set of 14 glass fragments, including objects and production remains dated to the 16th and 17th century and unearthed in Granada, were studied and their chemical composition was characterised by $\mu$-PIXE, which allowed for the discussion of the nature and origin of the employed raw materials and types of produced glass. 
The area where these glass production remains were excavated was known as Calle Horno del Vidrio (Glass Furnace Street), which in the past was the way used to indicate or designate the type of activity that was being developed in the street.

All the analysed glasses are soda-lime-silica glass, excluding sample HV-8, which is a potassium-rich glass. Concerning the silica sources, one group composed of eight samples was identified. This group presents cohesive characteristics allowing one to propose that these samples were made from the same source of silica, which is comparable with the so far analysed Castril glass. Within this very cohesive group, one may find one sample with a potassium-rich composition. This reinforces the suggestion that the furnaces were probably producing different glass types from the same silica source, meaning that for this specific sample, HV-8, the alkali source was different but the employed source of silica was not. However, with only one sample showing this behaviour, it is not possible to make any further conclusions. Still, analysing the silica sources, two samples, one showing Nasrid characteristics (HV-4) and the other with Castril characteristics (HV-5), are slightly different from the main group but appeared in close proximity to each other, leading one to propose that the same silica source (probably geographically close to the one employed for Group 1 samples) was used to produce both Nasrid and Castril glasses.

When crossing data from the Granada furnace with data from the analysis performed to glass excavated in Beja, Portugal (PMF), it is possible to strongly relate two PMF fragments with Group 1 samples. This could suggest that glass was already manufactured in Granada during the 14th/15th century, not only for local consumption, as the objects were also exported, at least to the south of Portugal. More data are needed in order to support this hypothesis.

Finally, when analysing the alkaline sources and apart from the K-rich sample, the same grouping observed for the silica sources is maintained. The whole set of samples is distributed along the previously defined groups in the literature as a function of the use of unpurified or purified ash treatment and the millefiori sample for instance appears in the area defined for façon-de-Venise glass from different provenances. What is striking is that Group 1 samples, which in the majority presents Castril characteristics, appear all together aligned in the region of purified ashes, forming a new group with characteristics not reported in the literature so far. We hope in the future, with further analysis, to be able to better explore this group, trying to disclose the followed recipe that implies the step of purifying the ashes.

This preliminary work reinforces the need to further study glass from the 14 th to 17 th century, chronologies that are not well explored. Moreover, glass from this period and from the Andalusian region is a 'rough diamond' with recipes and trading patterns yet to be found, which will probably change the current beliefs about glass production in the Iberian Peninsula.

Author Contributions: Conceptualisation, I.C. and T.M.; methodology, I.C., T.M. and L.C.A.; software, L.C.A. and I.C.; validation, I.C. and T.M.; formal analysis, I.C., I.C.C., L.C.A. and T.M.; investigation, I.C., I.C.C., L.C.A. and T.M.; resources, I.C., I.C.C., L.C.A. and T.M.; data curation, I.C., I.C.C., L.C.A. and T.M.; writing — original draft preparation, I.C. and T.M.; writing-review and editing, I.C., I.C.C., L.C.A. and T.M.; visualisation, I.C., I.C.C., L.C.A. and T.M.; supervision, I.C., I.C.C., L.C.A. and T.M.; project administration, I.C., I.C.C., L.C.A. and T.M.; funding acquisition, I.C. and L.C.A. All authors have read and agreed to the published version of the manuscript.

Funding: This work has been partially funded by the Fundação do Ministério de Ciência e Tecnologia de Portugal through the research unit VICARTE (UID/00729/2020) and through the research unit $\mathrm{C}^{2} \mathrm{TN}$ (UID/Multi/04349/2013).

Data Availability Statement: Not applicable.

Acknowledgments: The authors would like to thank to the reviewers, whose work helped improving the quality and readability of this paper.

Conflicts of Interest: The authors declare no conflict of interest. 


\section{References}

1. Frothingham, A.W. Spanish Glass; Faber: London, UK, 1963.

2. Domènech, I.V.I. El vidrio español de los siglos XVI a XVIII. In Frágil Transparencia. Vidrios Españoles de Los Siglos XVI a XVIII; Philippart, J.-P., Mergenthaler, M., Eds.; Verlag J.H. Röll GmbH: Dettelbach, Germany, 2011; pp. $19-61$.

3. Oliver, C.A. El taller de vidre medieval de Sant Fost de Campsentelles. Acta Hist. Archaeol. Mediaev. 1989, 10, $387-426$.

4. Barrachina, J. El Vidre. In El Castel de Llinars del Vallés; Monreal, L., Barrachina, J., Eds.; Abadia de Montserrat: Barcelona, Spain, 1983; pp. 207-234.

5. Galmés, M.À.C. ARS VITRARIA. Mallorca (1300-1700); UIB: Palma, Spain, 2015.

6. Liefkes, R. Glass; The Board of the Trustees of the Victoria and Albert Museum: London, UK, 1997.

7. Liefkes, R. Façon de Venise Glass in the Netherlands. In Beyond Venice: Glass in Venetian Style, 1500-1750; Page, J.-A., Ed.; The Corning Museum of Glass: Corning, NY, USA, 2004; pp. 227-249.

8. McCray, W.P. Glassmaking in renaissance Italy: The innovation of venetian cristallo. JOM 1998, 50, 14-19. [CrossRef]

9. García, J.L.G. El coleccionismo de vidrio artístico español en los siglos XVI y XVII. Bol. del Mus. E Inst. Camón Aznar 1998, 73, 111-139.

10. Moreno, M.J.S. La fabricación de vidrio en El Recuenco: Una industria olvidada. Cuad Etnol Guadalaj. 1997, 29, 205-270.

11. Barberán, V.G. Resumen histórico sobre la vidriera de Castril. In Castril, Testimonio; Mallorquín, A.T., Ed.; Diputacion Provincial De Granada: Castril, Granada, Spain, 1990; pp. 155-188.

12. Marcos, A.L.; Cobos, A.C.; Pertíñez, C.L. Excavación arqueológica de urgencia en la calle horno del vidrio, 16 (granada). Anu. Arqueol. Andal. 1998, 3, 275-286.

13. Martínez, J.F.R.; Linares, M.A.A.; Mondejar, F.G.; Milán, L.A. Estudio químico y mineralógico de un conjunto de vidrios de Castril (SS. XVII-XIX) (Granada). MACLA Rev. Soc. Esp. Miner. 2015, 20, 123-124.

14. García, J.M.C.; Martinez, J.M. Un lote de cerámica de Manises y vidrio de Castril (ss. XVII-XVIII) aparecido en la ciudad de Murcia. Estudio analítico de sus materiales. Verdolay Rev. Mus. Arqueol. Murcia 1991, 3, 141-162.

15. Doménech, I. Spanich Façon de Venise glass. In Beyond Venice: Glass in Venetian Style, 1500-1750; Page, J.-A., Ed.; The Corning Museum of Glass: Corning, NY, USA, 2004.

16. Govantes-Edwards, D.J.; Duckworth, C.N.; Córdoba, R.; De La Llave, R.C. Recipes and experimentation? The transmission of glassmaking techniques in Medieval Iberia. J. Medieval Iber. Stud. 2016, 8, 176-195. [CrossRef]

17. Coutinho, I.; Medici, T.; Alves, L.; Gratuze, B.; Vilarigues, M. Provenance studies on façon-de-Venise glass excavated in Portugal. J. Archaeol. Sci. Rep. 2016, 7, 437-448. [CrossRef]

18. Coutinho, I. New Insights into 17th and 18th Century Glass from Portugal: Study and Preservation; Universidade Nova de Lisboa: Carcavelos, Portugal, 2016.

19. Medici, T. Vidros da Terra, o Vidro Tardomedieval e Moderno em Portugal (Séculos XIV-XVII). O Contributo da Arqueologia; Faculdade de Letras da Universidade de Coimbra: Coimbra, Portugal, 2014.

20. Carmona, N.; Villegas, M.-A.; Jiménez, P.; Navarro, J.; García-Heras, M. Islamic glasses from Al-Andalus. Characterisation of materials from a Murcian workshop (12th century AD, Spain). J. Cult. Heritage 2009, 10, 439-445. [CrossRef]

21. Duckworth, C.N.; De La Llave, R.C.; Faber, E.W.; Edwards, D.J.G.; Henderson, J.C. Electron Microprobe Analysis of 9th-12th Century Islamic Glass from Córdoba, Spain. Archaeometry 2014, 57, 27-50. [CrossRef]

22. Ares, J.D.J.; Schibille, N. La Hispania antigua y medieval a través del vidrio: La aportación de la arqueometría. Bol. Soc. Esp. Cerám. Y Vidr. 2017, 56, 195-204. [CrossRef]

23. Ares, J.D.J.; Schibille, N. Glass import and production in Hispania during the early medieval period: The glass from Ciudad de Vascos (Toledo). PLoS ONE 2017, 12, e0182129. [CrossRef]

24. Heras, M.G. Estudio arqueométrico de los vidrios andalusíes procedentes del taller de la calle Puxmarina (Murcia). Verdolay Murcia 2008, 11, 277-302.

25. Ares, J.D.J.; Guirado, A.V.-E.; Gutiérrez, Y.C.; Schibille, N. Changes in the supply of eastern Mediterranean glasses to Visigothic Spain. J. Archaeol. Sci. 2019, 107, 23-31. [CrossRef]

26. Govantes-Edwards, D.; Duckworth, C.; de la Llave, R.C.; Aparicio Sánchez, L.; Camacho Cruz, C. El vidrio Andalusí su composición química: Primeros resultados y posibilidades de estudio. Bol. Arqueol. Mediev. 2014, 18, 31-49.

27. Murcia-Mascarós, S.; Roldan, C.; Falomir, C.; Domènech, I.; Carreras, J.; Ibáñez Puchades, R. Non-destructive analysis of enamelled 'façon-de-venise' glass discovered in morella (castelló, spain). In ANNALES of the 17th Congress of the International Association for the History of Glass (Antwerp 2006); Janssens, K., Degryse, P., Cosyns, P., Caen, J., Van't Dack, L., Eds.; University Press: Antwerp, Belgium, 2009; pp. 493-499.

28. Boyero, E.P. Hernando de zafra: Secretario real, oligarca granadino y señor de vasallos. Misc. Mediev. Murc. 2003, 175-208. [CrossRef]

29. Pareja, M.G. Hernando de Zafra, cortesano y hombre de empresa de los Reyes Católicos. Cuad. Estud. Mediev. Y Cienc. Y Téc. Hist. 1974, 2-3, 127-147.

30. Navarro, J.M.F. El Vidrio, Colección Textos Universitarios, No6, 3rd ed; Consejo Superior de Investigaciones Científicas Sociedad Española de Cerámica y Vidrio: Madrid, Spain, 2003.

31. Brems, D.; Degryse, P. Trace Element Analysis in Provenancing Roman Glass-Making. Archaeometry 2013, 56, 116-136. [CrossRef] 
32. Wedepohl, K.H.; Simon, K.; Kronz, A. Data on 61 chemical elements for the characterization of three major glass compositions in late antiquity and the middle ages. Archaeometry 2010, 53, 81-102. [CrossRef]

33. Moretti, C.; Hreglich, S. Raw Materials, Recipes and Procedures Used for Glass Making. In Modern Methods for Analysing Archaeological and Historical Glass; Wiley: Hoboken, NJ, USA, 2013; pp. $23-47$.

34. Velde, B. Glass Compositions over Several Millennia in the Western World. In Modern Methods for Analysing Archaeological and Historical Glass, Vol.I; Janssens, K., Ed.; Wiley: Chichester, UK, 2013; pp. 67-78.

35. Vilarigues, M.; Coutinho, I.; Medici, T.; Alves, L.; Gratuze, B.; Machado, A. From beams to glass: Determining compositions to study provenance and production techniques. Phys. Sci. Rev. 2019, 4, 1-24. [CrossRef]

36. Adlington, L.W. The Corning Archaeological Reference Glasses: New Values for “Old" Compositions. Pap. Inst. Archaeol. 2017, 27, 1-8. [CrossRef]

37. Verità, M.; Zecchin, S. Thousand Years of Venetian Glass: The evolution of chemical composition from the origins to the 18th century. In ANNALES of the 17th Congress of the International Association for the History of Glass; Janssens, K., Degryse, P., Cosyns, P., Caen, J., Van't Dack, L., Eds.; University Press: Antwerp, Belgium, 2009; pp. 602-613.

38. Verità, M. Venetian Soda Glass. In Modern Methods for Analysing Archaeological and Historical Glass V.II; Janssens, K., Ed.; John Wiley \& Sons, Ltd.: West Sussex, UK, 2013; pp. 515-536.

39. Dungworth, D. Glass-ceramic reactions in some post-medieval crucibles. Glass Technol. Eur. J. Glass Sci. Technol. Part A 2008, 49, 157-167.

40. Schibille, N.; Sterrett-Krause, A.; Freestone, I.C. Glass groups, glass supply and recycling in late Roman Carthage. Archaeol. Anthr. Sci. 2017, 9, 1223-1241. [CrossRef]

41. Coutinho, I.; Medici, T.; Alves, L.; Perović, Š. Colourless Roman glass from the Zadar necropolis: An exploratory approach. J. Archaeol. Sci. Rep. 2017, 15, 194-202. [CrossRef]

42. Coutinho, I.; Alves, L.C.; Medici, T. The Broken Piece of a Larger Picture: A Renaissance Enameled Glass Fragment Depicting a Triumphal Procession. J. Glass Stud. 2019, 61, 87-95.

43. Biron, I.; Verità, M. Analytical investigation on Renaissance Venetian enamelled glasses from the Louvre collections. J. Archaeol. Sci. 2012, 39, 2706-2713. [CrossRef]

44. Campaña, I.C. El Vidrio en La Alhambra-Desde el Period nazarí Hasta el Siglo XVII; Junta de Andalucía: Granada, Spain, 2016.

45. Girón-Pascual, R.M. Cenizas, cristal y jabón. El comercio de la barrilla y sus derivados entre España e Italia a finales del siglo XVI (1560-1610). eHumanista 2018, 38, 215-232.

46. Cagno, S.; Badano, M.B.; Mathis, F.; Strivay, D.; Janssens, K. Study of medieval glass fragments from Savona (Italy) and their relation with the glass produced in Altare. J. Archaeol. Sci. 2012, 39, 2191-2197. [CrossRef]

47. Coutinho, I.; Medici, T.; Coentro, S.; Alves, L.C.; Vilarigues, M. First archaeometric study on medieval glass found in Beja (Southern Portugal). J. Mediev. Iber. Stud. 2016, 8, 148-175. [CrossRef]

48. Lima, A.; Medici, T.; De Matos, A.P.; Verità, M. Chemical analysis of 17th century Millefiori glasses excavated in the Monastery of Sta. Clara-a-Velha, Portugal: Comparison with Venetian and façon-de-Venise production. J. Archaeol. Sci. 2012, 39, 1238-1248. [CrossRef]

49. Valente, F.P.; Coutinho, I.; Medici, T.; Vilarigues, M. Glass colored by glass: Review of the pick-up decoration in early modern Europe. J. Archaeol. Sci. Rep. 2021, 36, 102832. [CrossRef] 